\title{
Macroinvertebrate fauna associated with Pistia stratiotes and Nymphoides indica in subtropical lakes (south Brazil)
}

\author{
Albertoni, EF. ${ }^{\mathrm{a}, \mathrm{b} *}$, Prellvitz, LJ. $^{\mathrm{b}}$ and Palma-Silva, $C .^{\mathrm{b}}$ \\ aLaboratório de Ecologia, Departamento de Zoologia e Genética, Instituto de Biologia, \\ Universidade Federal de Pelotas, Campus Universitário, s/n, CP 354, CEP 96010-900, Pelotas, RS, Brazil \\ Laboratório de Limnologia, Departamento de Ciências Morfo-Biológicas, Fundação Universidade Federal do Rio Grande, \\ Av. Itália, Km 8, Campus Carreiros, CEP 96201-900, Rio Grande, RS, Brazil \\ *e-mail: edelti.albertoni@ufpel.edu.br
}

Received November 7, 2005 - Accepted March 1, 2006 - Distributed August 31, 2007

(With 5 figures)

\begin{abstract}
This study was carried out at the Biguás and Polegar lakes, both small environments but at different successional stages. The main objective was to characterize the macroinvertebrate community associated to the aquatic macrophyte stand in each lake in order for this community, the environmental conditions and their water quality to interact. The samples were taken in 2003. The abiotic variables of $\mathrm{N}$ and $\mathrm{P}$ totals, the temperature, electrical conductivity, $\mathrm{pH}$ and dissolved oxygen, as well as the determined clorophyll $a$ concentration were measured. Macroinvertebrates were sampled with a $500 \mu$ mesh size net, separated under a stereomicroscope and identified at the lowest possible taxonomic level, and their densities were shown as the number of individuals per $100 \mathrm{~g}$ of macrophyte dry weight. The Shannon-Wiener Diversity Index (H'), Pielou evenness (J), frequency of occurrence, abundance and taxa richness were calculated for each invertebrate community. The Lago dos Biguás is undergoing a process of eutrophication and during the study presented a large Pistia stratiotes stand. The Lago Polegar is oligotrophic and had only a small Nymphoides indica bankwe. The macrophyte associated invertebrate communities in each lake were considered significantly different $(\mathrm{p}<0.05)$. Sixty seven taxa were found for the Lago dos Biguás and 32 for the Lago Polegar. For both lakes, most of the taxa were considered rare, with a low dominance in a few months. The taxa with highest densities at Lago dos Biguás were Chironomidae, Daphniidae and Cyclopidae, and Oligochaeta, Chironomidae and Coenagrionidae for Lago Polegar.
\end{abstract}

Keywords: macroinvertebrates associated with macrophytes, communities, subtropical lakes.

\section{Fauna de macroinvertebrados associados a Pistia stratiotes e Nymphoides indica em lagos subtropicais (sul do Brasil)}

\begin{abstract}
Resumo
Este estudo foi realizado nos lagos dos Biguás e Polegar, ambientes de pequenas dimensões que se encontram em diferentes estágios sucessionais. O objetivo principal foi caracterizar a comunidade de macroinvertebrados, que vive associada ao estande de macrófitas aquáticas encontrado em cada um dos lagos, na tentativa de obter relações entre a comunidade, a saúde dos ambientes e a qualidade de água. As coletas foram feitas durante o ano de 2003. Em cada lago, foram avaliadas as concentrações de $\mathrm{N}$ e o $\mathrm{P}$ totais, o pH, temperatura, oxigênio dissolvido, condutividade elétrica, e determinadas as concentrações de clorofila $a$ na água. A malha utilizada para a separação dos macroinvertebrados foi de $500 \mu$ e os resultados de densidade foram expressos em 100 gramas de peso seco de macrófita. A triagem foi realizada sob estereomicroscópio e os organismos identificados até o menor nível taxonômico possível. Para cada comunidade foram calculados o Índice de Diversidade de Shannon-Wiener (H'), a homogeneidade de Pielou (J), a freqüência de ocorrência, a abundância e a riqueza de taxa. O Lago dos Biguás, em processo de eutrofização, apresentou durante o período estudado um grande estande de Pistia stratiotes. O Lago Polegar, oligotrófico, abrigou apenas pequenos bancos de Nymphoides indica. As comunidades de macroinvertebrados associados às macrófitas em cada lago foram consideradas significativamente diferentes $(\mathrm{p}<0,05)$. Foram encontrados 67 taxa no Lago dos Biguás e 32 no Lago Polegar. Nos dois ambientes, a maior parte dos taxa foi considerada rara, com pouca dominância em poucos meses. As maiores densidades foram de Chironomidae, Daphniidae e Cyclopidae no Lago dos Biguás, e de Oligochaeta, Chironomidae e Coenagrionidae no Lago Polegar.
\end{abstract}

Palavras-chave: macroinvertebrados associados às macrófitas, comunidades, lagos subtropicais. 


\section{Introduction}

The study of biological communities is used as an important tool when assessing environmental conditions and in freshwater communities, macroinvertebrates are one of the most studied (Poi de Neiff and Carignan, 1997; Galdean et al., 2000; Buffagny et al., 2001; Callisto et al., 2001; Waite et al., 2004, among others).

Biological assessment and criteria can be used as the basis for management programs, restoring and maintaining the chemical, physical and biological integrity of freshwater. Live organisms offer valuable information of the surrounding conditions and can be used to evaluate the physical, chemical and biological impact and their cumulative effects (Karr and Chu, 1999). According to the authors, surveys of the richness and species composition, the relative abundance of groups or species and the feeding relationships between the inhabiting organisms are the most direct measure to determine if a water body meets the biological standards for aquatic life.

Shallow freshwater ecosystems, such as wetlands, lagoons and streams are typical ecosystems on the Rio Grande do Sul coastal plain (Vieira and Rangel, 1988). Aquatic macrophytes are an extremely important community in these environments and possess rich associated macroinvertebrate fauna. Studies of the macroinvertebrate community of the northern part of the state's coastal plain have been conducted by Albertoni (1990), Albertoni and Würdig (1996) and Würdig et al. $(1990,1998)$ and to the southern region by Prellvitz and Albertoni (2004) and Albertoni et al. (2005).

Many species of aquatic macrophytes and their dense stands have an enormous spatial heterogeneity and therefore not only provide shelter for many species of invertebrates, but also play an important role in stabilizing environmental conditions (Nessimian and De Lima, 1997). They provide favorable conditions for many groups by serving as both a substrate and food source for herbivores and periphyton feeders, and subsequently for their predators (Glowacka et al, 1976; Wilcox and Meeker, 1992). Some studies showed that macrophytes could be used by invertebrates directly as food, and their role in their nutrition has been often underestimated (Sand-Jensen and Madsen, 1989).

According to Hynes (1970) and various authors after him, there is a direct relation between the quantity and richness of aquatic macrophytes and that of its associated fauna. In addition, Hargeby (1990) states that the aquatic macrophytes' seasonal growth is an important factor that may influence the abundance of invertebrates.

Pistia stratiotes Linnaeus 1753 is a floating aquatic macrophyte with a large submersed radicular system while Nymphoides indica (L.) Kuntze 1891 Kuntze is a rooted plant with floating leaves. These two species are very common in subtropical regions and can form dense stands in freshwater ecosystems (Cordazzo and Seeliger, 1988).

Despite the widespread occurrence of these and many other species of aquatic macrophytes in the freshwater systems of the Rio Grande do Sul coastal area and their environmental importance, very little is known about the associated macroinvertebrate communities in the southern part of the state.

For this reason, the aims of this study were to integrate the macroinvertebrate communities associated with aquatic macrophytes in two lakes at different successional stages to assess their space-time distribution; to evaluate the relationship between their density and abundance and some abiotic features of these water bodies.

\section{Material and Methods}

The city of Rio Grande is located on the southern part of the Rio Grande do Sul coastal plain in the morphic unit known as the Rio Grande sandy coastal plain (restinga) or Southern Barrier ( $32^{\circ} 01^{\prime} 40^{\prime \prime} \mathrm{S}$ and $52^{\circ} 05^{\prime} 40^{\prime \prime} \mathrm{W}$ ). This region was formed during the quaternary period by successive sea transgressions and regressions and nowadays is extremely rich in aquatic ecosystems (Vieira and Rangel, 1988). According to Vieira and Rangel (1988), the Rio Grande do Sul coastal plain is an extraordinary lake-lagoon hydrographic environment, also including streams and wetlands - all located in the sandy coastal plains area.

The climate is warm-temperate, with prevailing NE winds ( $5 \mathrm{~ms}^{-1}$ average speed), mean annual temperature of $17^{\circ} \mathrm{C}$ and annual pluviometric precipitation of 1200 to $1500 \mathrm{~mm}$. Seasonal variations in temperature can be determined by the mean monthly temperatures, which vary between $24{ }^{\circ} \mathrm{C}$ in January (summer) and $13{ }^{\circ} \mathrm{C}$ in July (winter), and by the mean precipitation, which is higher during the winter and spring (July to October) and lower during the summer months, leading to a seasonal shortage of water. Furthermore, precipitation varies significantly each year, causing periods of intense rain and prolonged drought which seem to be a consequence of the effects of the El Niño - Southern Oscillation cycle in the global climate (Seeliger et al.,1998).

The area, where the Carreiros Campus of the Fundação Universidade Federal do Rio Grande, Rio Grande's University is located, has a large number of small lakes, which for many years were the city's water supply source. Some of these lakes are natural, although they may have been modified for water exploitation. Others are manmade and were formed by the removal of sand used to construct the campus buildings. Two of these lakes were chosen for the present study. The choice was made based on their trophic characteristics and the colonizing species of aquatic macrophyte in each environment. Sampling was taken throughout 2003.

The Lago dos Biguás (Figure 1) has an area of 1.5 ha, a maximum depth of $1.6 \mathrm{~m}$ and was formed artificially by the removal of sand in order to construct the buildings of the Fundação Universidade Federal do Rio Grande (FURG) about 35 years ago. In spite of this, its characteristics are very similar to those of the natural lakes found on the coastal plain.

During the study period, the lake was subject to external sources of enrichment represented mainly by the 

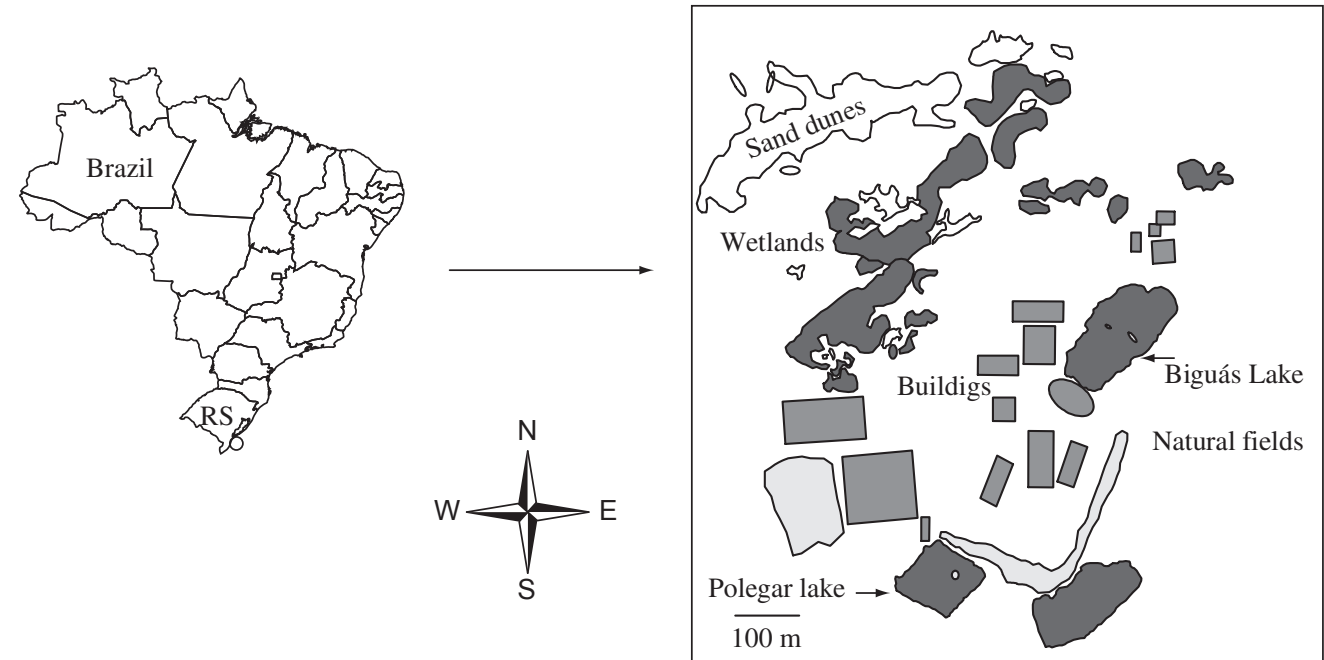

Figure 1. Carreiros Campus with sampling sites (Biguás and Polegar lakes) (32 $01^{\prime} 40^{\prime \prime} \mathrm{S}$ and $\left.52^{\circ} 05^{\prime} 40^{\prime \prime} \mathrm{W}\right)$.

faeces of groups of birds of the Egretta thula Molina, 1782 (small white heron), Phalacrocorax brasilianus Gmelin, 1789 (cormorant) and Dendrocygna viduata Linnaeus, 1766 (white-faced tree duck) species, which began to use the lake and its central island as shelter a few years ago. In addition to these species which are native to the region, the lake was also used for the rearing of geese (Anser anser) Linnaeus, 1758.

The Lago Polegar (Figure 1) is also manmade and has similar characteristics to natural environments in the region. It has an area of 0.7 ha, a maximum depth of $1.4 \mathrm{~m}$, is about 7 years old and is not subject to any external source of enriching. Small groups of white-faced tree ducks (Dendrocygna viduata) use it occasionally, but do not cause any measurable change in its water quality. During the study period, this lake was home to just one stand of the rooted macrophyte Nymphoides indica.

The macrophytes Pistia stratiotes and Nymphoides indica were collected in triplicate with the aid of a net with a mesh size of $500 \mu \mathrm{m}$. Measurements of temperature, dissolved oxygen (oximeter OAKTON), electric conductivity (conductivimeter HANNA) and $\mathrm{pH}$ (pHmeter HANNA) in the water column were also taken in situ for each lake, and a water sample carried out to the laboratory to measure chlorophyll $a$ by fluorometric lecture (Welschmeyer, 1994), and total organic Nitrogen (Kjehdahl) and total Phosphorous were analyzed according to Strickland and Parsons (1968). At the Lago dos Biguás, a visual estimation was also made of the surface covered by the macrophyte stand at each sampling date.

In the laboratory, the plants were washed with a $500 \mu \mathrm{m}$ sieve and then placed in an oven to determine the dry weight $(0.01 \mathrm{~g})$. After washing the plants, macroinvertebrates were preserved in $80 \%$ ethanol and separated under a stereomicroscope (40 $\mathrm{x}$ magnification). The macroinvertebrates were identified to the lowest possible taxonomic level and their densities shown as the number of individuals per $100 \mathrm{~g}$ of macrophyte dry weight.
The macroinvertebrate composition and structure were evaluated by diversity (Shannon-Wiener Index) evenness (Pielou Index) Magurran (1988) and abundance rates. The results were compared by a Student " $t$ " test. The occurrence was classified as the number of sampled as: very frequent $(>70 \%)$, frequent $(70-40 \%)$, low frequent $(40-10 \%)$ or sporadic $(<10 \%)$. The abundance was classified based on the individual's density as: dominant ( $>70 \%)$, abundant $(70-40 \%)$, low abundant $(40-10 \%)$ and rare $(<10 \%)$.

\section{Results and Discussion}

\subsection{Lago dos Biguás}

The enrichment of the lake was indicated by some abiotic variables, the changes in the environment which could be seen and the results of the analyses of the chlorophyll $a$ concentration. There was a great variation between the levels of $\mathrm{pH}$ and dissolved oxygen variables in the water column during the period and there were high levels of concentrations of nitrogen and phosphorous (Table 1). Moreover, there were blooms of phytoplankton in the lake, which was also home to a constantly-growing stand of the floating macrophyte Pistia stratiotes which, according to Kissmann (1991), often occurs in enriched environments.

The growth of the macrophyte stand was so intense that it totally covered the surface of the lake on some occasions. To avoid even greater enrichment of the environment from the decomposing of this stand, some of the plants were removed from the lake during the year by University staff. In July 2003, almost all the plants were removed. A small stand remained on the banks of the lake which made it possible to carry out two more samples in August. After this, the plants disappeared and did not grow back again.

\subsection{Lago Polegar}

There was little variation in the levels of $\mathrm{pH}$ and dissolved oxygen in the water column. Both these levels and 
those of the concentrations of total organic nitrogen and total phosphorous make it possible to characterize Lago Polegar as an oligotrophic environment (Table 1).

The macrophyte stand remained in the lake until the drought that occurred in the summer of 2003/2004 (December) began to dry it out, when sampling was not possible.

\subsection{Associated macroinvertebrate communities}

Based on the work of Thienemann at the beginning of the $20^{\text {th }}$ century, Schäfer (1980) established a relationship between extreme habitats, such as eutrophic waters and poor communities, characterized by a limited number of adapted species and their high dominance. In habitats which have balanced conditions, on the other hand, a biocoenosis richness in terms of the number of species and with uniform distribution of individuals can be found. In the two studied lakes, the associated macroinvertebrate communities were diverse and wellstructured, dominance was found in only a few months and most of the taxa were considered rare for the whole period (Table 2) suggesting that the communities found good environmental conditions for development, recognized by the lower levels of dominance.

Nevertheless, there were differences between the two ecosystems. The number of taxa (Table 2) found for Lago dos Biguás (67) was significantly higher than that found for Lago Polegar (32). In Lago dos Biguás, there was equilibrium between the groups which was considered very frequent (18), frequent (16), low frequent (14) and sporadic (17). In Lago Polegar, however, few groups were considered very frequent (5) and the majority was considered low frequent (12).

These results can mostly be explained by the macrophytes habit and morphology present in each lake, which differs to a degree of structural complexity concerning the environment. Pistia stratiotes floats and has a large radicular system available in the water column to be used as food and substrate by the macroinvertebrates. The microenvironment created by the huge stand of the above macrophyte, which was there even in the winter months (July/August) when the density of organisms in the region tends to be lower (Prellvitz and Albertoni; 2004), may have influenced other variables and may have been a determining factor in the high density and frequency of the taxa found.

Nymphoides indica, on the other hand, is a rooted plant which has a smaller area than $P$. stratiotes, formed only by its long petioles and the lower part of its floating leaves. Moreover, its stand remained small and sparse throughout the whole study period, causing the taxa associated to it to be subject to higher abiotic variation. According to Cyr and Downing (1988), the differences in numbers of invertebrates in various macrophyte associations are considered a result of joint impact of a number of parameters and factors, such as plant morphology, surface texture, epiphytic algal growth and nutrient content of plant tissues.

The values of the Shannon-Wiener (H') diversity index were significantly different (2.23 for Lago dos Biguás and 1.78 for Lago Polegar, $\mathrm{p}<0.05)$ suggesting that the former lake was able to sustain a richer associated community.

There were significant variations $(\mathrm{p}<0.05)$ in the diversity levels found for each lake throughout the months of the study period, reflected in the evenness levels (Figures 2 and 3). In most samplings, the environments studied showed median homogeneity, and the higher variation was found at Lago dos Biguás $(\mathrm{J}=0.57$ in January and 0.20 in April) (Figure 2). Lago Polegar showed evenness values varying between 0.56 in November and 0.25 in March (Figure 3). According to Shäfer (1980), high levels of evenness indicate an environment with heterogeneous conditions regulated by a community which is rich in the number of species and the multiplicity of their mutual relationships. The variations found suggest that conditions were extremely heterogeneous in some months and simplified in others leading to a less rich community structured in a simpler way.

In general, and when compared to the values found for other environments in the region and/or other studied years (Prellvitz and Albertoni, 2004; Albertoni et al., 2005), the evenness levels for this period cannot be considered high.

Table 1. Abiotic results of water column from two lakes at Carreiros Campus from January/2003 to August/2003 (Biguás Lake) and from January/2003 to December/2003 (Polegar Lake).

\begin{tabular}{lccccc}
\hline & \multicolumn{2}{c}{ Biguás $(\mathbf{n}=\mathbf{1 1})$} & & \multicolumn{2}{c}{ Polegar $(\mathbf{n}=\mathbf{1 5})$} \\
\cline { 2 - 3 } \cline { 5 - 6 } & Mean \pm SD & Min - Max & & Mean \pm SD & \multicolumn{1}{c}{ Min - Max } \\
\hline Temperature $\left({ }^{\circ} \mathrm{C}\right)$ & $22.7 \pm 5.4$ & $15-30$ & & $23.7 \pm 5.3$ & $16-30.5$ \\
Dissolved Oxygen $\left(\mathrm{mg} . \mathrm{L}^{-1}\right)$ & $7.72 \pm 3.6$ & $3.1-14.7$ & & $6.18 \pm 0.96$ & $5-8.5$ \\
$\mathrm{pH}$ & $8.06 \pm 1.59$ & $6.7-10.6$ & & $7.35 \pm 0.52$ & $6.8-8.6$ \\
Conductivity $\left(\mu \mathrm{S} . \mathrm{cm}^{-1}\right)$ & $144.7 \pm 46.1$ & $67.6-240.1$ & & $51.4 \pm 20.3$ & $37.0-119.2$ \\
Total Nitrogen $\left(\mathrm{mg} . \mathrm{L}^{-1}\right)$ & $5.31 \pm 2.8$ & $1.9-10.3$ & & $4.35 \pm 2.41$ & $1.53-9.9$ \\
Total Phosphorous $\left(\mathrm{mg} . \mathrm{L}^{-1}\right)$ & $1.13 \pm 0.67$ & $0.0-2.4$ & & $0.012 \pm 0.0107$ & $0.003-0.03$ \\
Clorophyll $a\left(\mu \mathrm{g} . \mathrm{L}^{-1}\right)$ & $14.2 \pm 16.1$ & $0.6-55.0$ & & $5.57 \pm 4.01$ & $0.6-11.7$ \\
\hline
\end{tabular}


Table 2. Taxonomic composition of invertebrates associated with aquatic macrophytes at Biguás and Polegar lakes during the study period ( R -Rare; LA - Little abundant; S - sporadic; LF - little frequent; F - frequent; VF - very frequent).

\begin{tabular}{|c|c|c|c|c|c|c|}
\hline \multicolumn{3}{|c|}{ Taxa } & \multicolumn{2}{|c|}{ Abundance } & \multicolumn{2}{|c|}{ Ocurrence } \\
\hline Class & Order & Family & Biguás & Polegar & Biguás & Polegar \\
\hline Hydrozoa & & & $\mathrm{R}$ & & $\mathrm{S}$ & \\
\hline Turbellaria & & & $\mathrm{R}$ & $\mathrm{R}$ & VF & LF \\
\hline Nemertea* & & & $\mathrm{R}$ & $\mathrm{R}$ & VF & $\mathrm{F}$ \\
\hline Nematoda* & & & & $\mathrm{R}$ & & $\mathrm{F}$ \\
\hline Gastropoda & & & $\mathrm{R}$ & $\mathrm{R}$ & VF & VF \\
\hline Oligochaeta & & & $\mathrm{R}$ & A & VF & VF \\
\hline Hirudinea & & & $\mathrm{R}$ & $\mathrm{R}$ & VF & LF \\
\hline \multirow[t]{2}{*}{ Arachnida } & Aranae & & $\mathrm{R}$ & & VF & \\
\hline & Acarina & & $\mathrm{R}$ & & VF & VF \\
\hline \multirow[t]{4}{*}{ Branchiopoda } & $\begin{array}{l}\text { Diplostraca - } \\
\text { Cladocera }\end{array}$ & Daphniidae & LA & $\mathrm{R}$ & VF & LF \\
\hline & & Macrothricidae & $\mathrm{R}$ & $\mathrm{R}$ & LF & LF \\
\hline & & Chydoridae & $\mathrm{R}$ & $\mathrm{R}$ & S & $\mathrm{F}$ \\
\hline & & Ilyocryptidae & $\mathrm{R}$ & & $\mathrm{F}$ & \\
\hline \multirow[t]{2}{*}{ Ostracoda } & Podocopa & Cyprididae & $\mathrm{R}$ & $\mathrm{R}$ & VF & LF \\
\hline & & Cytheridae & $\mathrm{R}$ & & $\mathrm{E}$ & \\
\hline \multirow[t]{2}{*}{ Copepoda } & Cyclopoida & Cyclopidae & LA & $\mathrm{R}$ & VF & $\mathrm{F}$ \\
\hline & Calanoida & Diaptomidae & $\mathrm{R}$ & $\mathrm{R}$ & $\mathrm{F}$ & LF \\
\hline Malacostraca - Peracarida & Amphipoda & Hyalellidae & $\mathrm{R}$ & & LF & \\
\hline \multirow[t]{28}{*}{ Insecta } & Collembola & Entomobrydae & $\mathrm{R}$ & & VF & \\
\hline & & Sminthurydae & $\mathrm{R}$ & & $\mathrm{F}$ & \\
\hline & Ephemeroptera & Baetidae & $\mathrm{R}$ & $\mathrm{R}$ & LF & LF \\
\hline & & Caenidae & $\mathrm{R}$ & $\mathrm{R}$ & VF & $\mathrm{F}$ \\
\hline & & Siphlonuridae & $\mathrm{R}$ & & S & \\
\hline & & Eutyplociidae & $\mathrm{R}$ & $\mathrm{R}$ & S & S \\
\hline & Odonata & Coenagrionidae & $\mathrm{R}$ & $\mathrm{R}$ & VF & VF \\
\hline & & Libellulidae & $\mathrm{R}$ & $\mathrm{R}$ & $\mathrm{F}$ & $\mathrm{LF}$ \\
\hline & & Gomphidae & $\mathrm{R}$ & $\mathrm{R}$ & S & LF \\
\hline & Orthoptera & Gryllidae & $\mathrm{R}$ & & $\mathrm{F}$ & \\
\hline & Plecoptera & Nemouridae & $\mathrm{R}$ & & S & \\
\hline & Hemiptera & & & & & \\
\hline & Heteroptera & Pleidae & $\mathrm{R}$ & & $\mathrm{F}$ & \\
\hline & & Saldidae & $\mathrm{R}$ & & $\mathrm{F}$ & \\
\hline & & Hebridae & $\mathrm{R}$ & & $\mathrm{F}$ & \\
\hline & & Belostomatidae & $\mathrm{R}$ & & LF & \\
\hline & & Veliidae & $\mathrm{R}$ & & VF & \\
\hline & & Gelastocoridae & & $\mathrm{R}$ & & $\mathrm{S}$ \\
\hline & & Corixidae & $\mathrm{R}$ & & LF & \\
\hline & Homoptera & Delphacidae & $\mathrm{R}$ & & VF & \\
\hline & & Aphididae & $\mathrm{R}$ & & $\mathrm{F}$ & \\
\hline & Coleoptera & Hydrophilidae & $\mathrm{R}$ & $\mathrm{R}$ & VF & S \\
\hline & & Curculionidae & $\mathrm{R}$ & $\mathrm{R}$ & $\mathrm{F}$ & S \\
\hline & & Dytiscidae & $\mathrm{R}$ & $\mathrm{R}$ & VF & LF \\
\hline & & Scirtidae & $\mathrm{R}$ & & $\mathrm{F}$ & \\
\hline & & Carabidae & $\mathrm{R}$ & & LF & \\
\hline & & Noteridae & $\mathrm{R}$ & & $\mathrm{F}$ & \\
\hline & & Staphylinidae & $\mathrm{R}$ & & $\mathrm{F}$ & \\
\hline
\end{tabular}


Table 2. Continued...

\begin{tabular}{|c|c|c|c|c|c|c|}
\hline \multicolumn{3}{|c|}{ Taxa } & \multicolumn{2}{|c|}{ Abundance } & \multicolumn{2}{|c|}{ Ocurrence } \\
\hline Class & Order & Family & Biguás & Polegar & Biguás & Polegar \\
\hline & & Elmidae & $\mathrm{R}$ & & $\mathrm{LF}$ & \\
\hline & & Limnichidae & $\mathrm{R}$ & $\mathrm{R}$ & $\mathrm{LF}$ & S \\
\hline & & Psephenidae & $\mathrm{R}$ & & S & \\
\hline & & Salpingidae & $\mathrm{R}$ & & S & \\
\hline & & Haliplidae & $\mathrm{R}$ & $\mathrm{R}$ & S & LF \\
\hline & Trichoptera & Hydroptilidae & $\mathrm{R}$ & $\mathrm{R}$ & $\mathrm{F}$ & $\mathrm{F}$ \\
\hline & & Leptoceridae & $\mathrm{R}$ & $\mathrm{R}$ & $\mathrm{LF}$ & $\mathrm{F}$ \\
\hline & Lepidoptera & Pyralidae & $\mathrm{R}$ & $\mathrm{R}$ & VF & $\mathrm{F}$ \\
\hline & & Noctuidae & $\mathrm{R}$ & & $\mathrm{LF}$ & \\
\hline & Diptera & Chironomidae & LA & LA & VF & VF \\
\hline & & Syrphidae & $\mathrm{R}$ & $\mathrm{R}$ & LF & $\mathrm{S}$ \\
\hline & & Stratiomydae & $\mathrm{R}$ & $\mathrm{R}$ & VF & $\mathrm{LF}$ \\
\hline & & Ephydridae & $\mathrm{R}$ & & $\mathrm{F}$ & \\
\hline & & Ceratopogonidae & $\mathrm{R}$ & & $\mathrm{F}$ & \\
\hline & & Dolichopodidae & $\mathrm{R}$ & & $\mathrm{S}$ & \\
\hline & & Muscidae & $\mathrm{R}$ & & $\mathrm{S}$ & \\
\hline & & Culicidae & $\mathrm{R}$ & & $\mathrm{LF}$ & \\
\hline \multirow[t]{8}{*}{ * Phyllum } & & Psychodidae & $\mathrm{R}$ & & S & \\
\hline & & Tabanidae & $\mathrm{R}$ & & S & \\
\hline & & Sciomizidae & $\mathrm{R}$ & & S & \\
\hline & Hymenoptera & Scelionidae & $\mathrm{R}$ & & $\mathrm{LF}$ & \\
\hline & & Braconidae & & $\mathrm{R}$ & & S \\
\hline & & Eulophidae & $\mathrm{R}$ & & S & \\
\hline & & Pteromalidae & $\mathrm{R}$ & & $\mathrm{S}$ & \\
\hline & & Diapriidae & $\mathrm{R}$ & & LF & \\
\hline
\end{tabular}

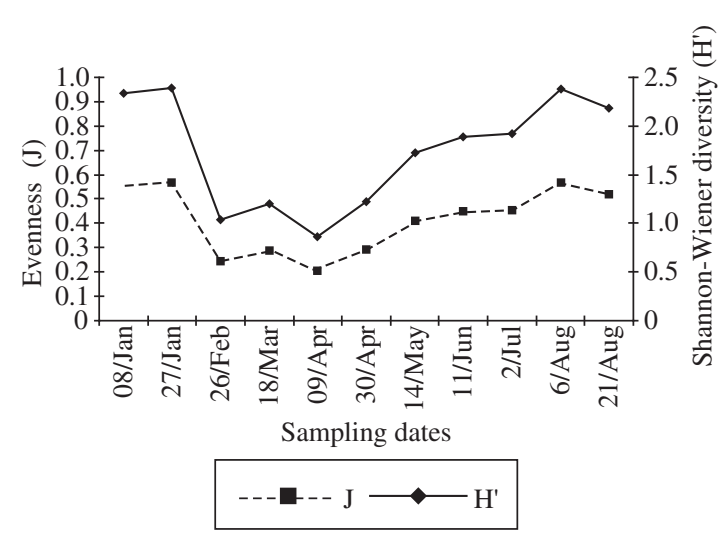

Figure 2. Shannon-Wiener Diversity (H') and Pielou evenness $(\mathrm{J})$ indices for Biguás Lake.

The wide diversity of groups also explains the taxonomic level in which the organisms found were classified. In most cases, taxonomic classification was done at family level. In some groups, however, it was not possible to go further than Phylum. This classification

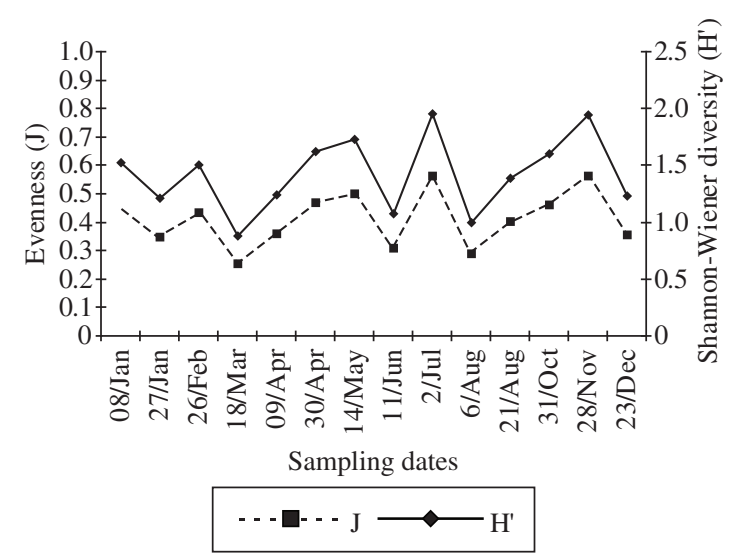

Figure 3. Shannon-Wiener Diversity (H') and Pielou evenness ( $\mathrm{J}$ ) indices for Polegar Lake.

level is widely used in studies to characterize macroinvertebrate communities, especially in South American countries where the species of organisms are unknown and there are limited human and financial resources (Alba-Tercedor and Sánchez-Ortega, 1988; Feldman 
and Connor, 1992; Callisto et al., 2000; Marques and Barbosa, 2001; Stenert et al., 2002 and 2004; Callisto et al., 2004; among others).

The density of organisms found in the Lago dos Biguás was over 20 times higher than that found in the Lago Polegar. The groups which had the highest densities for Lago dos Biguás were Chironomidae (Diptera), Daphnidae (Cladocera) and Cyclopidae (Copepoda), which together represented $65 \%$ of all the organisms collected (Figure 4). For the Lago Polegar, Oligochaeta, Chironomidae (Diptera) and Coenagrionidae (Odonata) represented $77 \%$ of all the organisms collected (Figure 5).

According to Di Giovani et al. (1996), the Chironomidae is almost always found to be numerically predominant, both in lotic and lentic environments, due to its tolerance to extreme conditions. According to Merritt and Cummins (1996), the range of conditions under which chironomids are found is more extensive than that of any other group of aquatic insects, and their wide ecological amplitude is related to the very extensive ar-

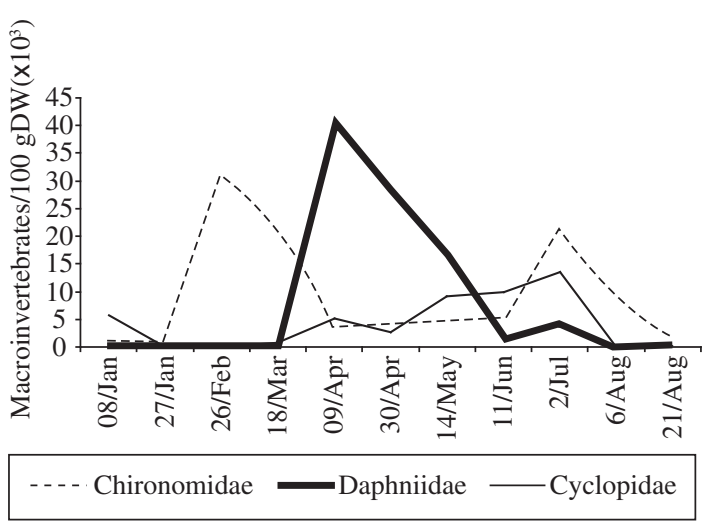

Figure 4. Temporal variation of the most abundant macroinvertebrate taxa at Biguás Lake.

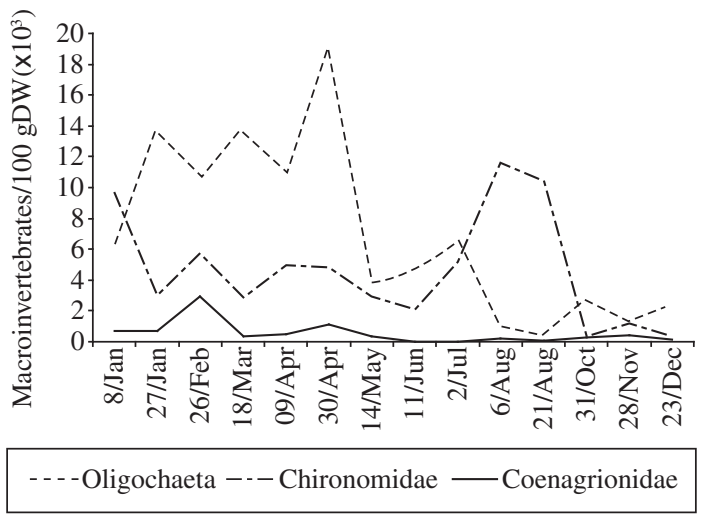

Figure 5. Temporal variation of the most abundant macroinvertebrate taxa at Polegar Lake. ray of morphological, physiological and behavioral adaptations.

Feeding habits may explain the predominance of the other groups which occurred in Lago dos Biguás. The large amount of phytoplankton which occurred in this lake, especially at the beginning of the study period, probably sustained the high density of Daphniidae, filtering Cladocera common in lentic environments (ElmoorLoureiro, 1997). Like all Cladocera, Daphniidae is able to reproduce parthenogenetically and can increase its population enormously in a short period of time, provided that there are both good environmental conditions and food available (Thorp and Covich, 1991).

The copepods of the Cyclopidae family, however, are carnivores and may prey on Cladocera (Williamson, 1991). They may, therefore, have increased their population also due to the great abundance of food, represented by the great number of Cladocera.

In Lago Polegar, the $N$. indica stand did not provide macroinvertebrates with a favorable habitat as $P$. stratiotes did. On the other hand, not as many variations in the abiotic characteristics occurred and the environment was more stable throughout the year. This may have contributed to the fact that it was particularly difficult to relate the dominance of the taxa found with any interaction between the groups or with the abiotic characteristics of the environment.

Oligochaeta is a typical detritivorous (Brinkhurst and Gelder, 1991). According to Trivinho-Strixino et al. (1997), the roots and other submersed parts of macrophytes accumulate detritus and large quantities of organic matter, favoring the establishment of populations of detritivorous and collector feeding organisms. Owing to other factors and interactions, the feeding habits of Oligochaeta may have contributed to its high densities.

Coenagrionidae (Odonata) are predatory insects (Westfall and Tenessen, 1996) and may use macrophytes as a substrate and also as an ambush point to capture their prey. The larvae are an important part of aquatic food webs and are useful subjects for research on the effects of stream pollution (Merritt and Cummins, 1996). We believe that the high density of these taxa at the Lago Polegar could be explained by the better water quality in this system, since some research has shown that they could be a good environmental condition indicator (Chandler, 1970).

The macroinvertebrate communities showed differences between the two studied lakes. The Lago dos Biguás housed a higher density community, a higher taxa number and greater diversity. These results could be explained by different nutrient conditions in the two lakes that enable different macrophyte species to grow. These environmental conditions provide richer macroinvertebrate community to plants with large radicular systems, such as $P$. stratiotes.

Acknowledgments - We would like to thank the Conselho Nacional de Desenvolvimento Científico e Tecnológico (CNPq) for the grant awarded to the second author, to Fundação de 
Amparo a Pesquisa do Estado do Rio Grande do Sul (FAPERGS, proc. 0409862) and an anonymous referee for the suggestions.

\section{References}

ALBA-TERCEDOR, A., and SÁNCHEZ-ORTEGA, J., 1988. Un método rápido y simple para avaluar la calidad biológica de las águas corrientes basado en el de Hellawell (1978). Limnetica, vol. 4, p. 51-56.

ALBERTONI, EF., 1990. Contribuição ao Estudo da Comunidade Fital de Zonas Litorâneas da Lagoa do Gentil - Tramandaí, RS. (Dissertação Mestrado) - Curso de PósGraduação em Ecologia, UFRGS. Porto Alegre.

ALBERTONI, EF. and WÜRDIG, NL., 1996. Comunidade de Ostracodes Associada a Macrófitas Aquáticas na Lagoa do Gentil, Tramandaí, RS. Acta Limnologica Brasiliensia, vol. 8, p. 103-114.

ALBERTONI, EF. PALMA-SILVA, C. and VEIGA, CC. 2005. Estrutura da Comunidade de Macroinvertebrados Associada às Macrófitas Aquáticas Nymphoides indica e Azzola filiculoides em dois Lagos Subtropicais (Rio Grande, RS). Acta Biologica Leopoldensia, vol. 27, no 2, p. 137-145.

BRINKHURST, RO. and GELDER, SR., 1991. Annelida: Oligochaeta and Branchiobdellida p 401-433. In THORP, JH. and COVICH, AP. (Eds), Ecology and Classification of North American Freshwater Invertebrates. San Diego: Academic Press. 911p. Chap. 18.

BUFFAGNI, A., KEMP, JL., ERBA, S., BELFIORE, C. HERING, D. AND MOOG, O. 2001. A Europe-wide system for assessing the quality of rivers using macroinvertebrates: the AQEM project and its importance for southern Europe (with special emphasis on Italy). Journal of Limnology, vol. 60 (Suppl. 1), p. 39-48.

CALlisto, M., BARBOSA, FAR. and MORENO, P., 2000. Macrobenthic diversity on different habitats in na altitudinal lake surrounded by Eucalyptus plantations and secondary Atlantic Forest (southeast Brazil). Acta Limnologica Brasiliensia, vol. 12, p. 55-61.

CAllisto, M., MORETTI, M. and GOULART, M., 2001. Macroinvertebrados bentônicos como ferramenta para avaliar a saúde de riachos. Revista Brasileira de Recursos Hídricos, vol. 6 , no. 1, p. $71-82$.

CAllisto, M., GOUlART, M., MEDEIROS, AO., MORENO, P. and Rosa, CA., 2004. Diversity Assessment of Benthic Macroinvertebrates, Yeasts, and Microbiological Indicators Along a Longitudinal Gradient in Serra do Cipó, Brazil. Brazilian Journal of Biology, vol. 64, no. 4, p. 743-755.

CHANDLER, JR., 1970. A biological approach to water quality management. Water Pollution Control, vol. 69, no. 2, p. $415-422$.

CORDAZZO, CA. and SEELINGER, U., 1988. Guia ilustrado da vegetação costeira no extremo sul do Brasil. Rio Grande: Ed. da FURG. 275p.

CYR, H. and DOWNING, JA. 1988. The abundance of phytophilous invertebrates on different species of submerged macrophytes. Freshwater Biology, vol. 20, no. 3, p. 365-374.

DI GIOVANI, MV., GORETTI, E. and TAMANTI, V., 1996. Macrobentos in Montedoglio Reservoir, central Italy. Hydrobiologia, vol. 321, no. 1, p. 17-28.
ELMOOR-LOUREIRO, LMA., 1997. Manual de Identificação de Cladóceros Límnicos do Brasil. Brasília: Ed. Universitária. $155 \mathrm{p}$.

FELDMAN, RS. AND CONNOR, EF., 1992. The relationship between $\mathrm{pH}$ and community structure of invertebrates in streams of the Shenandoah National Park, Virginia, U.S.A. Freshwater Biology, vol. 27, no. 2, p. 261-276.

GALDEAN, N., CALlisto, M. and BARBOSA, FAR., 2000. Lotic ecosystems of Serra do Cipó, southeast Brazil: water quality and a tentative classification based on the benthic macroinvertebrate community. Aquatic Ecosystem Health and Management, vol. 3, no. 4, p. 545-552.

GLOWACKA, I., SOSZKA, GJ. and SOSZKA, H., 1976. Invertebrates Associated with Macrophytes. In PIECZYNSKA, E. (Ed.), Selected Problems of Lake Littoral Ecology. University of Warsaw, Warsaw. Chap. 6. p 97-122.

HARGEBY, A., 1990. Macrophyte associated invertebrates and the effect of habitat permanence. Oikos, vol. 57, no. 3, p. 338-346.

HYNES, HBN., 1970. The diversity of macroinvertebrates and macrophyte communities in ponds. Freshwater Biology, vol. 18, no. 1 , p. $87-104$.

KARR, JR. and CHU, EW., 1999. Restoring life in running waters - Better biological monitoring. Washington: Island Press. 206p.

KISSMANN, KG., 1991. Plantas Infestantes e Nocivas. São Paulo: BASF Brasileira S.A. 602p.

MAGURRAN, AER., 1991. Ecological diversity and its measurement. London: Chapman and Hall, 178p.

MARQUES, MM. and BARBOSA, FAR., 2001. Biological quality of waters from an impacted tropical watershed (middle Rio Doce basin, southeast Brazil), using benthic macroinvertebrate communities as an indicator. Hydrobiologia, vol. 457 , no. $1 / 3$, p. $69-76$.

MERRITT, RW. and CUMMINS, KW., 1996. Aquatic Insects of the North America. Dubuque: Kendall/Hunt Publishing Company. 862p.

NESSIMIAN, JL. and DE LIMA, IHAG., 1997. Colonização de três espécies de macrófitas por macroinvertebrados aquáticos em um brejo no litoral do estado do Rio de Janeiro. Acta Limnologica Brasiliensia, vol. 9, p. 149-163.

POI DE NEIFF, A. and CARIGNAN, R., 1997. Macroinvertebrates on Eichhornia crassipes roots in two lakes of the Paraná River floodplain. Hydrobiologia, vol. 345, no. 3-4, p. $185-196$.

PRELLVITZ, LJ. and ALBERTONI, EF., 2004. Caracterização Temporal da Comunidade de Macroinvertebrados Associada a Salvinia spp. em um Arroio da Planície Costeira do Rio Grande do Sul (Rio Grande - RS). Acta Biologica Leopoldensia, vol. 26, no. 2, p. 213-223.

SAND-JENSEN, K. and MADSEN, TV., 1989. Invertebrates graze submerged rooted macrophytes in lowland streams. Oikos, vol. 55, no. 3, p. 420-423.

SCHÄFER, A., 1980. Critérios e Métodos para a Avaliação das Águas superficiais - Análise da Diversidade de Biocenoses. NIDECO Série Taim, no. 3. Porto Alegre: Ed. da Universidade Federal do Rio Grande do Sul, p. 24-41. 
SEELIGER, U., ODEBRECHT, C. and CASTELLO, JP. (Eds.), 1998. Os Ecossistemas Costeiro e Marinho do Extremo sul do Brasil. Rio Grande: Ecoscientia. 341p.

STENERT, C., SANTOS, EM., OLIVA, TD. and MALTCHIK, L., 2002. Diversidade de Macroinvertebrados em Áreas Úmidas na Bacia do Rio dos Sinos, RS, Brasil. Acta Biologica Leopoldensia, vol. 24, no. 2, p. 157-172.

STENERT, C., SANTOS, EM., and MALTCHIK, L., 2004. Levantamento da Diversidade de Macroinvertebrados em Áreas Úmidas do Rio Grande do Sul (Brasil). Acta Biologica Leopoldensia, vol. 26, no. 2, p. 225-240.

STRICKLAND, JDH. and PARSONS, TR. 1968. A practical handbook of seawater analysis. Bulletin of Fisheries Research Board of Canada, vol. 167, 311p.

THORP, JH. and COVICH, AP., 1991. Ecology and Classification of North American Freshwater Inverterbrates. San Diego: Academic Press. 911p.

TRIVINHO-STRIXINO, S., GESSNER, FA. and CORREIA, L., 1997. Macroinvertebrados associados a macrófitas aquáticas das lagoas marginais da estação ecológica de Jataí (Luiz Antônia - SP). Anais do Seminário Regional de Ecologia, vol. 8, p. 1189-1198.

VIEIRA, EF. and RANGEL,SR., 1988. Planície Costeira do Rio Grande do Sul. Porto Alegre: Sagra. 256p.

WAITE, IR., HERLIHY, AT., LARSEN, DP., URQUHART, S. and KLEMM, DL., 2004. The effects of macroinvertebrate taxonomic resolution in large landscape bioassessments: an example from the Mid-Atlantic Highlands, U.S.A. Freshwater Biology, vol. 49, no. 4, p. 474-489.

WELSCHMEYER, N., 1994. Fluorimetric analysis of chlorophyll $a$ in the presence of chlorophyll $b$ and pheopigments. Limnology and Oceanography, vol. 39, no. 8, p. 1985-1982.

WESTFALL JR., MJ. and TENESSEN, KJ., 1996. Odonata. In MERRITT, RW. and CUMMINS, KW. (Eds) Aquatic Insects of the North America. Dubuque: Kendall/Hunt Publishing Company. 862p.

WILCOX, DA. and MEEKER, JE., 1992. Implications for Faunal Habitat Related to Altered Macrophyte Structure in Regulated Lakes in Northern Minnesota. Wetlands, vol. 12, no. 3, p. 192-203.

WILIAMSON, CE., 1991. Copepoda. In THORP, JH. and COVICH, AP. (Eds), Ecology and Classification of North American Freshwater Invertebrates. San Diego: Academic Press. 911p. Chap.21. p 787-822.

WÜRDIG, NL., FREITAS, SF. and FAUSTO, I. DA V., 1990. Comunidade de ostracodes associada ao bentos e macrófitas aquáticas da Lagoa do Gentil, Tramandaí, Rio Grande do Sul. Acta Limnologica Brasiliensia, vol. 3, p. 807-828.

WÜRDIG, NL., ALBERTONI, EF., OZORIO, CP., WIEDENBRÜG, S. and RODRIGUES, G., 1998. The influence of environmental parameters in the structure of the benthic community in coastal lakes and lagoons of Rio Grande do Sul, Brazil. Internationale Verenigung für Theoretishe und Angewandte Limnologie, vol. 26, no. 3, p. 1514-1517. 
